\title{
Emerging Approaches to Stabilise Photocorrodible Electrodes and Catalysts for Solar Fuel Applications
}

\author{
Micaela Crespo-Quesada and Erwin Reisner
}

Christian Doppler Laboratory for Sustainable SynGas Chemistry, Department of Chemistry, University of Cambridge, Cambridge CB2 1EW, UK

Email: reisner@cam.ac.uk

Webpage: http://www-reisner.ch.cam.ac.uk 


\section{Abstract}

The generation of solar fuels through artificial photosynthesis could, in principle, solve our looming energy crisis. Photoelectrochemical devices use light-absorbers, such as semiconductors, to capture sunlight and generate excited states of charge carriers that are transported to catalysts for the production of solar fuels. However, the most suitable photoactive materials are often chemically unstable in contact with an aqueous electrolyte solution and therefore need protection by a conformal coating through a material that is chemically robust to prevent corrosion and conducting to allow transfer of charges to a solution-exposed catalytic site. Commonly used coating procedures and materials are extremely challenging to scale and therefore unlikely to be applicable on a scale to cover global demand. In this mini review, we present recent advances in this field revolving around unconventional, yet technically simpler and less costly routes to protecting and activating photocorrodible electrodes for solar fuels application. We focus on two emerging approaches: (i) the use of single source precursor chemistry for the preparation of bi-functional protecting and catalytically active layers, and (ii) the use of low-temperature fusible eutectic alloys as protecting and conducting layers that can be easily activated for catalysis. 


\section{Introduction}

The world is currently facing a steady increase in energy demand and consequently an accelerated depletion of fossil fuel resources. ${ }^{1}$ Photoelectrochemical (PEC) systems capture and convert solar energy in the chemical bonds of solar fuels and these approaches are widely pursued in the field of artificial photosynthesis. ${ }^{1}$ Solar-driven water splitting into $\mathrm{H}_{2}$ and $\mathrm{O}_{2}$ is potentially an attractive reaction from an economic point of view, due to the abundance of water and solar energy, coupled with the exceptionally high specific energy density $\left(33.3 \mathrm{kWh} \mathrm{kg}^{-1}\right)$ of $\mathrm{H}_{2}$ fuel. ${ }^{2,3}$

PEC cells employ light-harvesting materials such as semiconductors and catalysts to transform solar into chemical energy. Although only $1.23 \mathrm{~V}$ are required to overcome the thermodynamic barrier for water splitting, in practice, voltages of more than $1.8 \mathrm{~V}^{4}$ are necessary to overcome losses from solution resistance and overpotential (i.e., reaction kinetic barriers). Water splitting systems based on a single light absorber result in inefficient harvesting of solar light and can only reach a solar-to-hydrogen (STH) conversion efficiency of up to $12 \% .^{5}$ Tandem architectures with two small band gap semiconductors give a theoretical ceiling of $31 \%$ efficiency and have therefore been proposed as a much more attractive approach for PEC solar fuels synthesis. ${ }^{6,7} \mathrm{~A}$ recent review shows that these values descend to $5.4 \%$ (single light absorber) and 16.2\% (tandem configuration) when using realistic estimations of earth abundant photoelectrodes. ${ }^{8}$

However, while UV-absorbing, i.e. wide bandgap, materials are frequently stable, narrow band gap materials are often photocorroded under water 
splitting conditions. Furthermore, the catalysts used in conjunction with the semiconductors also degrade over time, thus aggravating the effect. Developing scalable protection strategies that allow the stable operation of small band gap materials during water splitting (and other solar fuel forming reactions) and enable the sustained operation of suitable catalysts is therefore of paramount importance for the advancement of tandem PEC cells and efficient solar fuel synthesis.

In this mini-review, we will first give a brief background on PEC cells and summarise the most frequently used method to protect photocorrodible materials, i.e., surface passivation with thin film techniques. The main part will then focus on emerging methods for protecting unstable semiconductors and prolonging the lifetime of catalytic materials for use in solar fuel production, with an emphasis on the use of fusible alloys and single source precursor (SSP) chemistry for this purpose.

\section{Photocorrodible materials in PEC cells}

PEC devices are usually composed by a semiconductor/electrolyte junction to effect the separation of charge carriers upon photoexcitation. ${ }^{9}$ Tandem semiconductor electrode-based PEC cells can consist of two photoelectrodes (Fig.1a) or of a monolithically integrated combination of two photoelectrodes in a single structure (Fig. $1 \mathrm{~b}) .{ }^{9}$ Extensive reviews present numerous examples of such PEC configurations for water splitting in the past few decades. ${ }^{10-14}$

A primary strategy for realising efficient PEC cells is the use of two 
semiconductors placed optically and electrically in series, which are coupled with a suitable $\mathrm{H}_{2}$ evolution catalyst (HEC) and $\mathrm{O}_{2}$ evolution catalyst (OEC). An optimum tandem solar-driven water-splitting system consists in theory of a pair of semiconductors with a band gap of $1.60-1.80 \mathrm{eV}$ as the top layer and 0.95-1.20 eV as the bottom layer. ${ }^{5-7,15}$ These band gap requirements rule out the use of most known oxide semiconductors and suggest the suitability of Group IV, III-V, II-VI, and chalcopyrite semiconductors as light absorbers. ${ }^{16}$

It is often useful to study these materials' performance first individually. In this case, photocathodes (Fig.1c) or photoanodes (Fig.1d) are paired with a dark electrode and are electrically biased to study the $\mathrm{H}_{2}$ evolution reaction (HER) or $\mathrm{O}_{2}$ evolution reaction $(\mathrm{OER})$, respectively. $\mathrm{Si}\left(\mathrm{E}_{\mathrm{g}}=1.1 \mathrm{eV}\right)$ and $\mathrm{Cu}_{2} \mathrm{O}\left(\mathrm{E}_{\mathrm{g}}=\right.$ $2.2 \mathrm{eV})$ are commonly used as photocathodes. $\mathrm{WO}_{3}\left(\mathrm{E}_{\mathrm{g}}=2.8 \mathrm{eV}\right), \mathrm{Fe}_{2} \mathrm{O}_{3}\left(\mathrm{E}_{\mathrm{g}}\right.$ $=2.2 \mathrm{eV})$ and $\mathrm{BiVO}_{4}\left(\mathrm{E}_{\mathrm{g}}=2.5 \mathrm{eV}\right)$ are often employed as photoanodes. These materials are popular due to their (sometimes direct) relatively narrow bandgaps, which allow harvesting the visible region of the solar spectrum, and suitable band positioning with respect to the water reduction and oxidation potentials. They are then coupled with suitable HECs (conventionally Pt, NiMo, CoP, $\mathrm{MoS}_{2}$, etc.) and $\mathrm{OEC}$ (conventionally $\mathrm{IrO}_{2}, \mathrm{RuO}_{2}$ and $\mathrm{NiFeO}_{x}$, etc.). ${ }^{17}$ Recent efforts using density functional theory calculations have allowed the prediction and preparation of mixed metal and earth abundant catalysts suitable for HER and OER. ${ }^{18}$

PEC cells can also be biased with a photovoltaic (PV) element and form PVbiased PEC cells, as shown in Fig.1e. If the PV element is able to deliver all of the required voltage for the water splitting reaction, it can be coupled directly 
to a suitable HEC and OEC to reduce protons and oxidise water, respectively (Fig.1f). A well-known example of the latter approach is the artificial leaf, where a commercial triple junction amorphous Si solar cell was interfaced with a self-assembled, ${ }^{19}$ self-healing, ${ }^{20}$ cobalt-phosphate (CoPi) OEC and NiMoZnalloy as HEC. This design initially achieved an STH of $4.7 \%$ in wired and $2.5 \%$ in wireless configuration. ${ }^{21}$ The catalysts used in the system have evolved over time to incorporate the bacterium Ralstonia eutropha ${ }^{22}$ to reduce $\mathrm{CO}_{2}$ in the dark, which if wired to a $18 \%$ efficiency solar cell would yield solar-to-fuel efficiencies of $10 \% .^{23}$ Lead halide perovskites (PVKs) are another excellent example for the approach shown in Fig. $1 \mathrm{f}$ as they have revolutionised the PV field in recent years with efficiencies of over $22 \%$ being now certified. ${ }^{24}$ Their limited stability however, in particular in the presence of moisture, has prevented their use in aqueous medium. As an initial proof of concept, two PVK PV cells in series kept in air were wired to a bifunctional Ni/Fe layered double hydroxide grown on $\mathrm{Ni}$ foam electrocatalyst submerged in an alkaline electrolyte solution to produce $\mathrm{H}_{2}$ at a STH efficiency of $12.3 \%{ }^{25}$

PVK cells have also been used in tandem configuration, as shown in Fig. 1e, where the PVK solar cell was kept in air and was connected to a photoelectrode submerged in the electrolyte. Hematite-PVK using CoPi and $\mathrm{Pt}$ as OEC and HEC tandem cells have reached a STH efficiency of $2.4 \%$ in 1 $\mathrm{M} \mathrm{NaOH}$ solutions following the configuration shown in Fig.1e. ${ }^{26} \mathrm{BiVO}_{4}$-based photoanodes coupled with a single PVK solar cell kept in air yielded STH conversion efficiencies of $2.5 \%$ also using CoPi and Pt as OEC and HEC (0.1 $\mathrm{M}$ phosphate buffer, $\mathrm{pH} 7),{ }^{27}$ which has recently been improved to $6.2 \%$ by 
doping the $\mathrm{BiVO}_{4}$ material with $\mathrm{Mo}$ and using $\mathrm{Fe}(\mathrm{Ni}) \mathrm{OOH}$ and $\mathrm{Pt}$ as $\mathrm{OEC}$ and HEC (0.5 M phosphate buffer, $\mathrm{pH} 7){ }^{28}$

However, both the semiconductors and catalysts used in configurations 1a to 1f for this application are typically unstable and undergo degradation under water splitting conditions.

Indeed, in the case of PV-biased PEC cells discussed above, the PV element is usually kept encapsulated outside the electrolyte solution and can show lifetimes of thousands of hours, the electrocatalysts are immersed in solution to drive the water splitting reaction and often degrade over time, sometimes in a matter of minutes. ${ }^{29}$

On the other hand, corrosion of semiconductors is an ubiquitous problem, which consists in the destruction of a material under the chemical or electrochemical action of the surrounding environment. ${ }^{30}$ Photocorrosion occurs when the anodic (or cathodic) corrosion potential of the semiconductor lies within its band gap. In this case, photocorrosion is competitive with the water splitting half reactions but the former is typically less energetic and thus thermodynamically more favorable leading to dominating corrosion phenomena. $^{31-33}$ Corrosion can produce either soluble or insoluble decomposition products. ${ }^{16}$ The former results in the dissolution of the semiconductor, whereas the latter decomposes the semiconducting properties and can form insulating layers that cause deactivation over time or effectively block the photogenerated carriers from reaching the electrode-electrolyte interface or catalyst site. ${ }^{34}$ 
Stabilisation of semiconductors and the long-term stability of catalysts are thus highly important and a requirement for the development of scalable and industrially relevant solar fuel technologies. Conventional techniques (Table 1) have revolved around using chemically stable coatings. $\mathrm{TiO}_{2}$ is by far the most studied material, as justified by its Pourbaix diagram that predicts its chemical stability in $\mathrm{pH} \mathrm{0-14} \mathrm{electrolyte} \mathrm{solutions} \mathrm{within} \mathrm{several} \mathrm{hundreds} \mathrm{of}$ $\mathrm{mV}$ of cathodic and anodic overpotentials. ${ }^{35}$ However, these layers must be thin enough to allow interfacial charge transfer (in particular at potentials where $\mathrm{TiO}_{2}$ is insulating), but at the same time thick and conformal to provide chemical resistance to the electrolyte solution.

Alternative techniques aiming at extending the lifetime of photoelectrodes and electrocatalysis, referred to here as emerging, have been reported in the literature in the past few years. These techniques are based on protection mechanisms different from surface passivation (Figure 2) and provide an alternative to the conventional thin film approach. Emerging techniques are in principle, of easier preparation, better scalability and in some cases have already shown stabilities comparable with thin film technologies.

Both conventional and emerging protection methods have been summarised Table 1 and Fig. 2. Table 1 groups the approaches in the conventional/emerging categories and provides a detailed description of each approach and its reported use and results. It is worth noting that the reported stability of most of the examples gathered in Table 1 does not make reference to the lifetime of the materials. Indeed, stability tests are often performed for an arbitrary amount of time, after which the performance of the photoelectrodes is still significantly high. Therefore, their actual lifetime (or 
even half-life) is potentially higher than the values reported in Table 1. Figure 2 , on the other hand, separates the approaches in terms of the element that is intended to be stabilised and the governing principle of the protection mechanism.

\section{Conventional protection mechanisms for unstable semiconductors}

The most common approach to protect unstable photoelectrodes is coating them with films that are more stable towards photocorrosion both thermodynamically and kinetically.

Nowadays, unstable semiconductors are coated with nanometre-scale thin films of materials including metals or metallic silicides, ${ }^{36-38}$ wide band gap semiconductors, ${ }^{39}$ transparent conducting oxides, ${ }^{34,40}$ transition metals and its oxides, $^{39,41}$ and organic polymers. ${ }^{42}$ Most recent studies deal with the fabrication of these protective layers using atomic layer deposition (ALD), ${ }^{43}$ which is a subset of CVD techniques that allows for ultra-thin films with limited charge transfer resistance. Physical vapour deposition (PVD) also allows for conformal and thickness controlled deposition of protecting materials. Other classical techniques such as electrodeposition, sol-gel, chemical bath, and spray deposition have a low cost of implementation but often result in porous films. ${ }^{16}$ The porosity diminishes the efficacy of anti-corrosion coatings since it can allow the electrolyte to reach the surface of the underlying layer. These methods have been studied extensively and have been the focus of several reviews. $^{16,33,39-41,43}$

Research into surface protection of photocorrodible semiconductors has been undergoing for several decades. While most early results were based on a 
relatively thick layers of $\mathrm{TiO}_{2}$ prepared by sol-gel, ${ }^{44}$ or chemical vapour deposition $(C V D)^{45}$ techniques. As a result, the protected semiconductor photoelectrodes had often poor PEC performance due to a substantial voltage drop across the resistive films. ${ }^{40,46}$ Modern thin film technology now allows for an effective protection of semiconductors. Indeed, as seen on Table 1, protection layers prepared through conventional approaches have already been reported to stabilise the photoelectrodes for periods ranging from $20 \mathrm{~min}$ to close to $100 \mathrm{~h}$ over a wide range of $\mathrm{pH}$ conditions.

It is worth noting that a conformal overlayer protects a photoactive material and often times forms a buried junction, ${ }^{9}$ which has the advantage that the absolute band edge position is decoupled from the thermodynamic water splitting potentials and that losses associated with non-ideal band positioning are eliminated. ${ }^{47}$ Indeed, in contrast to conventional PEC cells, alignment of the semiconductor band energies with the redox potentials for the half reactions of water splitting is not required and a sufficient photovoltage of around 1.8 to $2.0 \mathrm{~V}$ is sufficient to drive water splitting. The buried junction thus relaxes the constraints imposed by a classical PEC device because it separates light absorption from catalysis, and does not require the light absorber to be stable in aqueous electrolytes in which the $\mathrm{pH}$ regime for the absorber and best water-splitting catalyst may not be compatible. ${ }^{4}$

The widely used $\mathrm{TiO}_{2}$ ALD protection layers, while allowing for conformal and thickness control, are also challenging to scale up for commercialisation of solar fuels technology. Furthermore, catalytically active layers must still be deposited on top of the protection layer. 
An illustrative example is $\mathrm{Cu}_{2} \mathrm{O}$ photocathodes for $\mathrm{H}_{2}$ evolution. $\mathrm{Cu}_{2} \mathrm{O}$ is an attractive material for tandem water splitting systems since it is a p-type semiconductor with a direct bandgap of $2 \mathrm{eV}$, which corresponds to a maximum theoretical photocurrent of $14.7 \mathrm{~mA} \mathrm{~cm}^{-2}{ }^{48} \mathrm{Cu}_{2} \mathrm{O}$ displayed modest activities until the demonstration of ALD protection $\left(5 \times\left(4 \mathrm{~nm} \mathrm{ZnO} / 0.17 \mathrm{~nm} \mathrm{Al} \mathrm{O}_{3}\right) / 11 \mathrm{~nm} \mathrm{TiO}_{2}\right)$ with $\mathrm{Pt}$ as a catalyst showed a high PEC photocurrent for oxide materials under AM1.5 G illumination. ${ }^{47,49}$ This work spurred research on precious-metal free catalysts to be combined with the stabilised $\mathrm{Cu}_{2} \mathrm{O}$ photocathode and a range of HECs were deposited on top of the protection layer: $\mathrm{Pt},{ }^{49} \mathrm{RuO}_{\mathrm{x}},{ }^{50}$ and $\mathrm{MoS}_{\mathrm{x}}{ }^{51} \mathrm{TiO}_{2}$-protected $\mathrm{Si}$ photocathodes have also been reported, where $\mathrm{Pt}^{52-56}$ and even enzymes ${ }^{57}$ have been used as catalysts for $\mathrm{H}_{2}$ evolution.

Surface layers that protect and act as catalytic site can be considered as bifunctional layers. These type of layers are preferred since their presence has been linked to improved solar-to-fuel conversion efficiency by hindering the degradation of the light-harvester through the decrease of accumulated charges. $^{58}$ Furthermore, this approach also decreases the cost and complexity of the sample preparation, as it does not require a two-step procedure. Examples of this approach for protecting Si photocathodes with multifunctional layers are $\mathrm{MoS}_{2},{ }^{59} \mathrm{CoS}_{2},{ }^{60} \mathrm{NiO}_{\mathrm{x}},{ }^{61} \mathrm{NiRuO}_{\mathrm{x}}{ }^{62}$ and amorphous $\mathrm{CoO}_{\mathrm{x}}{ }^{63}$ Bifunctional coatings have also been successful for $\mathrm{Cu}_{2} \mathrm{O}$ : a $10 \mathrm{~nm}$ $\mathrm{NiO}_{\mathrm{x}}$ film was deposited onto a $\mathrm{Cu}_{2} \mathrm{O}$ nanowire photocathode by a sequential spin-coating followed by an annealing protocol to protect the light absorber and this layer also improves charge transfer across the electrode/electrolyte interface with $\mathrm{NiO}_{\mathrm{x}}$ acting as an electrocatalyst for $\mathrm{H}_{2}$ evolution. ${ }^{64}$ This 
photocathode was paired with a $\mathrm{WO}_{3}$ photoanode and constituted the first reported example of a tandem water splitting PEC cell with a pair of metal oxide semiconductors that operated without applied bias. ${ }^{64}$

\section{Emerging protection mechanisms for unstable semiconductors}

Several innovative and more scalable approaches have been recently explored to tackle the instability of narrow band-gap semiconductors and catalysts under water-splitting conditions. We have grouped the approaches by the governing principle of the protecting mechanism (Figure 2), namely charge quenching (which includes single source precursor chemistry, nanoparticles and other layers) and encapsulation.

\section{Semiconductor protection by charge quenching}

Single source precursor chemistry. Solution processed SSP chemistry is an attractive approach for preparing multifunctional materials on a large scale, as it bypasses the need for expensive equipment and processing. A SSP contains all of the required elements for a desired composite material, allowing for its synthesis in a simple, one-step procedure. The selection of a suitable SSP allows for the production of mono-, bi- and multifunctional coatings.

In recent years, a highly versatile and scalable SSP approach for preparing multifunctional films on photoelectrodes has been developed. ${ }^{65-69}$ Hydrolytic decomposition of titanium or polyoxotitanate compounds results in amorphous $\mathrm{TiO}_{2}$ films in a single-step. ${ }^{70}$ Heterobimetallic polyoxotitanate nanocages $\left[\mathrm{Ti}_{\mathrm{x}} \mathrm{O}_{\mathrm{y}}(\mathrm{OR})_{\mathrm{z}} \mathrm{M}_{\mathrm{n}}\right]$ (where $\mathrm{M}$ is a transition metal dopant) can be used as a 
readily-hydrolysable SSP for the generation of $\mathrm{M}$-doped $\mathrm{TiO}_{2}$ coatings (TiM) with tunable nanostructures and electro- and photochemical properties. SSPS such as those depicted in Fig. 3 (TiNi and TiCo) were selected because they hydrolyse quickly to form amorphous $\mathrm{TiO}_{2}$ as protective coating and precatalytic $\mathrm{Ni}$ and Co species, which are among the best-known noble metalfree HECs and OECs.

Intriguingly, $\mathrm{Ni}$ and $\mathrm{Co}$ species have also been shown to be bifunctional catalysts in water splitting catalysis, ${ }^{71-73}$ which gives the heterobimetallic SSPs a wide scope for applications as multifunctional coatings. Fig. 3 shows schematically the procedure to produce a protecting and catalytically active layer in a single spin-coating step and with the TiCo and TiNi containing SSPs. The precursors were hydrolysed upon spin-coating or drop-casting, which led to an amorphous $\mathrm{Ti}-, \mathrm{Ni}-$ or Co- containing precursor composite film $\left(\mathrm{TiM}_{\mathrm{pre}}\right){ }^{65}$ TiNi and TiCo are activated under cathodic conditions giving rise to $\mathrm{Ni}$ embedded in amorphous $\mathrm{NiO} / \mathrm{Ni}(\mathrm{OH})_{2}$ and $\mathrm{TiO}_{2}$ matrix, or $\mathrm{Co}$ embedded in amorphous $\mathrm{CoO}_{\mathrm{x}} / \mathrm{Co}(\mathrm{OH})_{2}$ and $\mathrm{TiO}_{2}$ matrix as $\mathrm{HEC}$ ( $\mathrm{TiM}_{\mathrm{HEC}}$ ). Anodic activation led instead to $\mathrm{NiO}_{\mathrm{x}}$ or $\mathrm{CoO}_{\mathrm{x}}$ embedded in $\mathrm{TiO}_{2}$ as $\mathrm{OEC}\left(\mathrm{TiM}_{\mathrm{OEC}}\right){ }^{65}$ The $\mathrm{TiO}_{2}$ layer prepared through this method was found to increase the stability of the photoelectrodes even though it could not be classically considered a thin film. Its protective qualities probably arise from a chargequenching effect, where the photogenerated charges are removed from the photoactive material and are trapped in the $\mathrm{TiO}_{2}$ layer, thus hindering the selfcorrosion of the material. ${ }^{74}$

Assembly of a tandem PEC cell could be demonstrated by pairing a Si 
photocathode and a $\mathrm{WO}_{3}$ photoanode both coated with the same TiNi SSP for overall solar-driven water splitting. ${ }^{65}$ These PEC cells demonstrate the suitability of TiNi as trifunctional SSP as it acted as a protective film, HEC and OEC. A PEC cell with p-Si coated with the TiNi SSP and $\mathrm{BiVO}_{4}$ covered with TiCo provided close-to-quantitative $\mathrm{H}_{2}$ and $\mathrm{O}_{2}$ gas generation with an appliedbias solar-to-hydrogen efficiency of $0.59 \%$. By scaling to a midsized tandem PEC cell with these electrodes, total photocurrent of approximately $2 \mathrm{~mA}$ at an applied bias of $0.6 \mathrm{~V}$ was generated. ${ }^{65}$

Although SSP chemistry is not yet able to generate totally conformal protection layers, its charge quenching capabilities have shown increased stabilities and activities thus making it a viable alternative to conventional methods, with extremely facile preparation, multifunctional character, and good stabilities.

Charge quenching with nanoparticles and other layers. Deposition of nanoparticles directly on top of a photocorrodible semiconductor can significantly suppress the corrosion reaction as was demonstrated by spincoating $\mathrm{Ni}$ nanoparticles onto the surface of $\mathrm{a} \mathrm{Cu}_{2} \mathrm{O} / \mathrm{CuO}$ photocathode. ${ }^{74}$ After 20 min of simulated solar illumination, the nickel decorated $\mathrm{Cu}_{2} \mathrm{O} \mid \mathrm{CuO}$ heterojunction retained 1.5 times more of the initial photocurrent than a bare $\mathrm{Cu}_{2} \mathrm{O}$ CuO. ${ }^{74}$ Nanoparticles presumably aid in decreasing corrosion by rapidly quenching the photogenerated charges ${ }^{75}$. Since the rate of both anodic and cathodic corrosion depends on the concentration of holes and electrons, $^{76}$ respectively, a decrease in the latter would slow photodegradation. 
An alternative charge quenching approach that does not share the disadvantage of the non-conformal nature of nanoparticles used ferrihydrite as a hole-storage layer that was able to protect unstable $\mathrm{Ta}_{3} \mathrm{~N}_{5}, \mathrm{TaON}$ and $\mathrm{BiVO}_{4}$ photoanodes against photocorrosion. With overlying $\mathrm{Co}_{3} \mathrm{O}_{4}$ nanoparticles as catalyst, the $\mathrm{Ta}_{3} \mathrm{~N}_{5} /$ ferrihydrite $/ \mathrm{Co}_{3} \mathrm{O}_{4}$ remained at about $94 \%$ of the initial activity after $6 \mathrm{~h}$ irradiation becoming the most durable of the $\mathrm{Ta}_{3} \mathrm{~N}_{5}$ based photoanodes reported to date. ${ }^{77}$

\section{Semiconductor protection by encapsulation}

Eutectic fusible alloys as protecting and conducting layers. Lead-halide PVKs have already surpassed efficiencies of over $20 \%$ and are the fastestdeveloping technology in the history of photovoltaics. ${ }^{24}$ However, their infamous fragility in the presence of traces of water, even low amounts of moisture, makes them unsuitable for direct use as light harvesters in aqueous solution for the production of $\mathrm{H}_{2}$ through water splitting. ${ }^{36,38}$

However, the PVK can be protected by a simple metal-encapsulating technique that is scalable and potentially also applicable to a wide range of photocorrodible materials. Field's metal, a fusible InBiSn alloy, has been employed as a protecting and conducting layer for the highly unstable $\mathrm{CH}_{3} \mathrm{NH}_{3} \mathrm{Pbl}_{3} \mathrm{PVK}^{37}$ When a layer of this material is placed on top of a PVK solar cell, it is capable of shielding it from water while simultaneously allowing the transport of the photogenerated electrons to the top of the device, where they can reach a co-integrated HEC such as $\mathrm{Pt}$ to produce $\mathrm{H}_{2}$ (see Fig. 4a). The surface of the Field's metal can be readily functionalised either by creating a thin oxide surface layer, to which catalysts could be anchored, or simply by depositing the catalyst through electroless deposition. 
The average photocurrent density obtained at $0 \mathrm{~V}$ versus RHE was $6.9 \pm 1.8$ $\mathrm{mA} \mathrm{cm}{ }^{-2}$, with a record device at $9.8 \mathrm{~mA} \mathrm{~cm}^{-2}$ and with an onset potential as positive as $0.95 \pm 0.03 \vee$ versus RHE (Fig. 4b). The photocathodes retained $80 \%$ of their initial photocurrent for more than $1.5 \mathrm{~h}$ in aqueous solution under chopped AM 1.5G irradiation (see Fig. 4c), and approximately $1 \mathrm{~h}$ under continuous illumination, which is remarkably long considering that unprotected PVK materials degrade within seconds when submerged in water $^{37}$ Furthermore, the stability of these photocathodes could potentially be improved significantly by changing the metallic contact layer between PCBM and Field's Metal to an inert metal, such as Au or removing it altogether.

The main drawback of this approach is that the photoelectrodes cannot be illuminated from the front, and must therefore be able to be prepared on a transparent substrate. On the other hand, this has also an advantage, as light will be reflected at the metal coating back into the electrode, thus increasing the photons absorbed and charges generated.

A further advantage of this method is the fact that the protecting eutectic metal can be easily recycled almost indefinitely by detaching it from the electrode, cleaning it and melting it. This decreases the effective cost of each protected photoelectrode and is aligned with a potential industrial application.

The utilisation of eutectics as protection layers is currently performed at a macroscopic level. Although there is hitherto no nano- or microscopic control in this emerging deposition technique, future developments using this approach are expected to overcome this limitation. It is for this reason that we included an evaporated metallic charge collection layer to improve charge transport in our first report. ${ }^{37}$ However, preliminary results show that the direct 
contact between Field's Metal and the underlying PCBM allows for efficient charge transport and can yield good performing water splitting cells.

\section{Emerging approaches for long-term stability of catalysts}

Self-healing and regeneration. Long-term stability in the order of a decade or more will ultimately be required for commercialisation of solar fuels technology. Self-repair has been demonstrated to prolong the lifetime of catalytically active species through in situ catalyst formation as a repair mechanism. A well-known example is a cobalt-phosphate (Co-Pi) water oxidation catalyst that can be formed in situ under anodic conditions (see Fig. 5a). ${ }^{20} \mathrm{Co}^{2+}$ formed and released into solution during water-oxidation catalysis will be redeposited upon oxidation to $\mathrm{Co}^{3+}$ in the presence of phosphate and re-generated the active OEC. ${ }^{20}$

A novel approach for regeneration of bifunctional and scalable iron-only materials for water splitting was recently reported. ${ }^{78} \mathrm{HEC}$ and OEC activity is caused by a facile and reversible inter-conversion of an oxide-supported $\mathrm{Fe}^{0}$ phase active for HER under a cathodic bias into an iron oxide-hydroxide $\left(\mathrm{FeO}_{\mathrm{x}}\right)$ phase active for OER under an anodic bias (see Fig. 5b). Biasswitching can thereby interconvert the iron anode into a cathode reversibly, which significantly enhanced stability and lifetime of a water electrolyser system with negligible activity loss for three days. ${ }^{78}$ Bias-switching may enable the stabilisation of PV- (or even wind) driven electrolysers that suffer from stability issues from fluctuating current densities. 
In situ regeneration was also achieved in a $\mathrm{CuRhO}_{2}$ p-type semiconductor that showed increased stability for PEC $\mathrm{H}_{2}$ evolution in the presence of air than $\mathrm{Ar}$. $\mathrm{CuRhO}_{2}$ photocorrodes under HER conditions to yield inactive $\mathrm{Cu}(0)$, which was re-oxidised to active $\mathrm{Cu}(\mathrm{I})$ in the presence of $\mathrm{O}_{2}{ }^{79}$ The rapidly developing field of $\mathrm{O}_{2}$ tolerant proton reduction catalysis has been reviewed recently ${ }^{80}$.

Although regeneration and self-healing has mainly been demonstrated for catalysts, this approach could in principle be extended to the photoabsorbers, or their protecting layers as well.

Superhydrophobic materials. The solar industry uses superhydrophobic materials in the form of transparent coatings to minimise the reflection of light and grant self-cleaning properties to outdoor solar cells. ${ }^{81,82} \mathrm{~A}$ recent review demonstrates simple colloidal techniques for preparing hierarchical structures that can produce sophisticated functions, such as superhydrophobicity. ${ }^{83}$ Superhydrophobic metallic Cu surfaces exhibit greatly enhanced antireflection without any chemical modification. Furthermore, their corrosion in an aqueous $\mathrm{NaCl}$ electrolyte solution was dramatically hindered due to enhancement of polarisation resistance. ${ }^{84}$ Hierarchical $\mathrm{TiO}_{2}$ nanorods decorated with $\mathrm{ZnO}$ have shown a dramatic change of the wetting behaviour of the top surface toward hydrophobicity. ${ }^{85}$

In superhydrophobic surfaces, the non-wetting behaviour is caused by the presence of a gaseous interlayer on the submerged surface. ${ }^{86}$ Therefore, submerged superhydrophobic materials experience performance loss. To address this limitation, PEC water splitting was employed to refill the escaping 
air interlayers on $\mathrm{SiC} / \mathrm{Si}^{87}$ hierarchical structures and ultra efficient $\mathrm{Pt}$ nanostructured electrodes. ${ }^{88}$ Furthermore, they found that the pine-shaped $\mathrm{Pt}$ nanostructured electrode had a lower gas bubble contact area and subsequently lower gas bubble adhesion force giving rise to active $(\approx 3.85 \mathrm{~mA}$ $\mathrm{mV}^{-1}, 13.75$ times higher than Pt flat electrode) and steady HER performance $(\approx 100 \%$ retention after $36 \mathrm{~h}){ }^{88}$ The preparation of structured hierarchical ITO electrodes by self-assembly has also been reported, and the technique could potentially also be used to render electrode surfaces superhydrophobic. ${ }^{89}$ Thus, the use of biomimetic superhydrophobic materials for water splitting is a promising approach that could potentially protect the underlying light harvester from the electrolyte solution and maximise the performance of the catalyst. 


\section{Summary and perspective}

Artificial photosynthesis allows storing energy as a chemical fuel and complements photovoltaic technology as it directly addresses the intermittence problem of electricity generation. Combinations of narrow bandgap semiconductors with suitable catalysts would yield the highest STH efficiencies for this application, but such materials are often unstable under water splitting conditions.

Conventionally, the issue of photoelectrode instability has been tacked with thin film technology. The vast majority of literature on this subject deals with thin films of wide band gap semiconductor materials (such as $\mathrm{TiO}_{2}$ and $\mathrm{ZnO}$ ) deposited through operationally costly techniques, such as ALD or sputtering. While these techniques allow the formation of conformal and nm-thin protection layers, the preparation is technically demanding and challenging to be scalable for global demand. However, even in the cases where photoelectrode instability was successfully hindered with ALD coatings, the problem of catalyst degradation in such systems still persists.

In this review, we have introduced emerging methods for protecting and activating unstable light-harvesting materials. Firstly, charge quenching techniques were introduced. Single source precursor chemistry was introduced as a special case to generate multifunctional layers able to both protect and drive the $\mathrm{H}_{2}$ and/or $\mathrm{O}_{2}$ evolution reactions in one simple preparation procedure. Secondly, we showed the use of fusible alloys to protect highly unstable materials, such as lead halide PVKs. This approach, where a protecting and electrically conducting layer of a fusible alloy was placed on top of a highly unstable PVK layer showing a record stability for this 
material in aqueous solution, is potentially applicable to other photocorrodible materials and might even increase the efficiencies since it features a two-pass light path, which would increase the amount of photons absorbed and thus the current generated. Other types of charge quenching layers as well as nanoparticles were also presented as special cases of this method.

In order to prolong the lifetime of the cataysts involved in water splitting, we also presented nascent biomimetic methods such as self-healing (which has already shown very promising results) and superhydrophobic materials (which have also the potential of protecting the underlying semiconductor).

Despite the promise of these approaches, there are still many challenges in designing stable and active photoelectrodes for water splitting. Ultimately, the method of choice should be simple, cost-effective and scalable.

Conventional methods have greatly helped to understand the underlying degradation mechanisms. However, they usually lack a study on the stability of the catalysts used in the systems. Indeed, both the stability of the semiconductor and the catalyst (perhaps by combining some of the methods presented in this review) must be addressed and they should increase by several orders of magnitude compared to the state-of-the-art systems.

While the emerging methods are relatively new, they already show great promise. Fusible alloy protection stability could be improved by using an inert intermediate layer, such as Au, or avoiding it altogether. Superhydrophobicity and self-repair mechanisms have already shown stabilities of several hundreds of hours. In our opinion, the biomimetic methods presented in this review should be combined with semiconductor protection methods in order to tackle both issues simultaneously. 


\section{Acknowledgements}

This work was supported by the People Programme (Marie Curie Actions) of the European Union's Seventh Framework Programme FP7-PEOPLE-2013IEF under REA Grant Agreement No. (623061; M.C-Q.) and the Christian Doppler Research Association (Austrian Federal Ministry of Science, Research and Economy and the National Foundation for Research, Technology and Development) and the OMV Group (E.R.). 


\section{References}

1 N. Armaroli and V. Balzani, Angew. Chemie Int. Ed., 2007, 46, 52-66.

2 K. Rajeshwar, P. Singh and J. DuBow, Electrochim. Acta, 1978, 23, $1117-1144$

3 P. P. Edwards, V. L. Kuznetsov, W. I. F. David and N. P. Brandon, Energy Policy, 2008, 36, 4356-4362.

4 C. R. Cox, J. Z. Lee, D. G. Nocera and T. Buonassisi, Proc. Natl. Acad. Sci. U. S. A., 2014, 111, 14057-14061.

$5 \quad$ M. S. Prévot and K. Sivula, J. Phys. Chem. C, 2013, 117, 1787917893.

6 S. Hu, C. Xiang, S. Haussener, A. D. Berger and N. S. Lewis, Energy Environ. Sci., 2013, 6, 2984-2993.

7 J. R. Bolton, S. J. Strickler and J. S. Connolly, Nature, 1985, 316, 495500.

8 K. T. Fountaine, H. J. Lewerenz and H. A. Atwater, Nat. Commun., 2016, 7, 13706.

9 A. C. Nielander, M. R. Shaner, K. M. Papadantonakis, S. A. Francis and N. S. Lewis, Energy Environ. Sci., 2015, 8, 16-25.

10 R. Abe, J. Photochem. Photobiol. C Photochem. Rev., 2010, 11, 179209.

11 M. G. Walter, E. L. Warren, J. R. McKone, S. W. Boettcher, Q. Mi, E. A. Santori and N. S. Lewis, Chem. Rev., 2010, 110, 6446-6473.

12 T. Hisatomi, J. Kubota and K. Domen, Chem. Soc. Rev., 2014, 43, $7520-7535$.

13 Y. Tachibana, L. Vayssieres and J. R. Durrant, Nat. Photonics, 2012, 6, 
$511-518$.

14 X. Chen, S. Shen, L. Guo and S. S. Mao, Chem. Rev., 2010, 110, 6503-6570.

15 T. J. Jacobsson, V. Fjällström, M. Edoff and T. Edvinsson, Sol. Energy Mater. Sol. Cells, 2015, 138, 86-95.

16 S. Hu, N. S. Lewis, J. W. Ager, J. Yang, J. R. McKone and N. C.

Strandwitz, J. Phys. Chem. C, 2015, 119, 24201-24228.

17 J. H. Montoya, L. C. Seitz, P. Chakthranont, A. Vojvodic, T. F. Jaramillo and J. K. Norskov, Nat Mater, 2017, 16, 70-81.

18 I. Roger, M. A. Shipman and M. D. Symes, Nat. Rev. Chem., 2017, 1, 3.

19 M. W. Kanan and D. G. Nocera, Science, 2008, 321.

20 D. A. Lutterman, Y. Surendranath and D. G. Nocera, J. Am. Chem. Soc., 2009, 131, 3838-3839.

21 S. Y. Reece, J. A. Hamel, K. Sung, T. D. Jarvi, A. J. Esswein, J. J. H. Pijpers and D. G. Nocera, Science, 2011, 334, 645-648.

22 J. P. Torella, C. J. Gagliardi, J. S. Chen, D. K. Bediako, B. Colón, J. C. Way, P. A. Silver and D. G. Nocera, Proc. Natl. Acad. Sci. U. S. A., 2015, 112, 2337-2342.

23 C. Liu, B. C. Colón, M. Ziesack, P. A. Silver and D. G. Nocera, Science, 2016, 352.

24 NREL, Efficiency Chart, accessed in November 2016, http://www.nrel.gov/pv/assets/images/efficiency_chart.jpg.

25 J. Luo, J.-H. Im, M. T. Mayer, M. Schreier, M. K. Nazeeruddin, N.-G. Park, S. D. Tilley, H. J. Fan and M. Gratzel, Science, 2014, 345, 15931596. 
26 Gurudayal, D. Sabba, M. H. Kumar, L. H. Wong, J. Barber, M. Grätzel and N. Mathews, Nano Lett., 2015, 15, 3833-3839.

27 Y.-S. Chen, J. S. Manser and P. V Kamat, J. Am. Chem. Soc., 2014, $137,974-981$.

28 Y. Qiu, W. Liu, W. Chen, W. Chen, G. Zhou, P.-C. Hsu, R. Zhang, Z. Liang, S. Fan, Y. Zhang and Y. Cui, Sci. Adv., 2016, 2, e1501764.

29 P. Du and R. Eisenberg, Energy Environ. Sci., 2012, 5, 6012-6021.

30 M. Pourbaix, Lectures on Electrochemical Corrosion, 1973.

31 A. J. Bard and M. S. Wrighton, J. Electrochem. Soc. , 1977, 124, 17061710.

32 M. Pourbaix, National Association of Corrosion Engineers, Houston, TX, 1974.

33 T. Wang and J. Gong, Angew. Chemie Int. Ed., 2015, 54, 1071810732.

34 K. Sun, S. Shen, J. S. Cheung, X. Pang, N. Park, J. Zhou, Y. Hu, Z. Sun, S. Y. Noh, C. T. Riley, P. K. L. Yu, S. Jin and D. Wang, Phys. Chem. Chem. Phys., 2014, 16, 4612.

P. Acevedo-Peña, J. Vazquez-Arenas, R. Cabrera-Sierra, L. LartundoRojas and I. González, J. Electrochem. Soc. , 2013, 160, C277-C284.

36 P. Da, M. Cha, L. Sun, Y. Wu, Z.-S. Wang and G. Zheng, Nano Lett., $2015,15,3452-3457$.

37 M. Crespo-Quesada, L. M. Pazos-Outón, J. Warnan, M. F. Kuehnel, R. H. Friend and E. Reisner, Nat. Commun., 2016, 7, 12555.

38 M. T. Hoang, N. D. Pham, J. H. Han, J. M. Gardner and I. Oh, ACS Appl. Mater. Interfaces, 2016, 8, 11904-11909. 
M. F. Lichterman, K. Sun, S. Hu, X. Zhou, M. T. McDowell, M. R.

Shaner, M. H. Richter, E. J. Crumlin, A. I. Carim, F. H. Saadi, B. S.

Brunschwig and N. S. Lewis, Catal. Today, 2016, 262, 11-23.

40 R. Liu, Z. Zheng, J. Spurgeon and X. Yang, Energy Environ. Sci., 2014, 7, 2504-2517.

41 T. Singh, T. Lehnen, T. Leuning and S. Mathur, J. Vac. Sci. Technol. A Vacuum, Surfaces, Film., 2015, 33, 010801.

42 S. Mubeen, J. Lee, N. Singh, M. Moskovits and E. W. McFarland, Energy Environ. Sci., 2013, 6, 1633-1639.

43 A. G. Scheuermann and P. C. Mclntyre, J. Phys. Chem. Lett., 2016, 7, 2867-2878.

44 R. B. Pettit and C. J. Brinker, Sol. Energy Mater., 1986, 14, 269-287.

45 P. A. Kohl, J. Electrochem. Soc., 1977, 124, 225-229.

46 D. G. Canfield and S. Roy Morrison, Appl. Surf. Sci., 1982, 10, 493505.

47 R. Wick and S. D. Tilley, J. Phys. Chem. C, 2015, 119, 26243-26257.

48 Y.-F. Lim, C. S. Chua, C. J. J. Lee and D. Chi, Phys. Chem. Chem. Phys., 2014, 16, 25928-25934.

49 A. Paracchino, V. Laporte, K. Sivula, M. Grätzel and E. Thimsen, Nat. Mater., 2011, 10, 456-461.

50 S. D. Tilley, M. Schreier, J. Azevedo, M. Stefik and M. Graetzel, Adv. Funct. Mater., 2014, 24, 303-311.

51 C. G. Morales-Guio, S. D. Tilley, H. Vrubel, M. Grätzel and X. Hu, Nat. Commun., 2014, 5, 3059.

52 B. Seger, D. S. Tilley, T. Pedersen, P. C. K. Vesborg, O. Hansen, M. 
Grätzel and I. Chorkendorff, RSC Adv., 2013, 3, 25902-25907.

B. Seger, T. Pedersen, A. B. Laursen, P. C. K. Vesborg, O. Hansen and

I. Chorkendorff, J. Am. Chem. Soc., 2013, 135, 1057-1064.

54 S. Li, P. Zhang, X. Song and L. Gao, ACS Appl. Mater. Interfaces, $2015,7,18560-18565$.

55 D. Bae, S. Shayestehaminzadeh, E. B. Thorsteinsson, T. Pedersen, O. Hansen, B. Seger, P. C. K. Vesborg, S. Ólafsson and I. Chorkendorff, Sol. Energy Mater. Sol. Cells, 2016, 144, 758-765.

56 D. M. Andoshe, S. Choi, Y.-S. Shim, S. H. Lee, Y. Kim, C. W. Moon, D. H. Kim, S. Y. Lee, T. Kim, H. K. Park, M. G. Lee, J.-M. Jeon, K. T. Nam, M. Kim, J. K. Kim, J. Oh and H. W. Jang, J. Mater. Chem. A, 2016, 4, 9477-9485.

57 C.-Y. Lee, H. S. Park, J. C. Fontecilla-Camps and E. Reisner, Angew. Chemie Int. Ed., 2016, 55, 5971-5974.

58 Z. Li, J. Feng, S. Yan and Z. Zou, Nano Today, 2015, 10, 468-486.

59 A. B. Laursen, T. Pedersen, P. Malacrida, B. Seger, O. Hansen, P. C. K. Vesborg and I. Chorkendorff, Phys. Chem. Chem. Phys., 2013, 15, 20000-20004.

60 C.-J. Chen, P.-T. Chen, M. Basu, K.-C. Yang, Y.-R. Lu, C.-L. Dong, C.G. Ma, C.-C. Shen, S.-F. Hu and R.-S. Liu, J. Mater. Chem. A, 2015, 3, 23466-23476.

61 K. Sun, N. Park, Z. Sun, J. Zhou, J. Wang, X. Pang, S. Shen, S. Y. Noh, Y. Jing, S. Jin, P. K. L. Yu and D. Wang, Energy Environ. Sci., 2012, 5, $7872-7877$.

62 K. Sun, X. Pang, S. Shen, X. Qian, J. S. Cheung and D. Wang, Nano 
Lett., 2013, 13, 2064-2072.

63 J. Yang, K. Walczak, E. Anzenberg, F. M. Toma, G. Yuan, J. Beeman, A. Schwartzberg, Y. Lin, M. Hettick, A. Javey, J. W. Ager, J. Yano, H. Frei and I. D. Sharp, J. Am. Chem. Soc., 2014, 136, 6191-6194.

64 C.-Y. Lin, Y.-H. Lai, D. Mersch and E. Reisner, Chem. Sci., 2012, 3, 3482-3487.

65 Y. H. Lai, D. W. Palm and E. Reisner, Adv. Energy Mater., 2015, 5, 1501668.

66 Y.-H. Lai, T. C. King, D. S. Wright and E. Reisner, Chem. - A Eur. J., 2013, 19, 12943-12947.

67 Y. H. Lai, H. S. Park, J. Z. Zhang, P. D. Matthews, D. S. Wright and E. Reisner, Chem. - A Eur. J., 2015, 21, 3919-3923.

68 Y.-H. Lai, C.-Y. Lin, Y. Lv, T. C. King, A. Steiner, N. M. Muresan, L. Gan, D. S. Wright and E. Reisner, Chem. Commun., 2013, 2, 43314333.

69 Y.-H. Lai, M. Kato, D. Mersch and E. Reisner, Faraday Discuss., 2014, $176,199-211$.

70 N. Li, P. D. Matthews, H.-K. Luo and D. S. Wright, Chem. Commun., 2016, 52, 11180-11190.

71 S. Cobo, J. Heidkamp, P.-A. Jacques, J. Fize, V. Fourmond, L. Guetaz, B. Jousselme, V. Ivanova, H. Dau, S. Palacin, M. Fontecave and V. Artero, Nat. Mater., 2012, 11, 802-807.

72 N. Jiang, B. You, M. Sheng and Y. Sun, Angew. Chemie Int. Ed., 2015, $54,6251-6254$.

73 L.-A. Stern, L. Feng, F. Song and X. Hu, Energy Environ. Sci., 2015, 8, 
$2347-2351$.

74 A. A. Dubale, C.-J. Pan, A. G. Tamirat, H.-M. Chen, W.-N. Su, C.-H.

Chen, J. Rick, D. W. Ayele, B. A. Aragaw, J.-F. Lee, Y.-W. Yang and B.J. Hwang, J. Mater. Chem. A, 2015, 3, 12482-12499.

75 S. Cao, X. Yan, Z. Kang, Q. Liang, X. Liao and Y. Zhang, Nano Energy, 2016, 24, 25-31.

76 H. Gerischer and W. Mindt, Electrochim. Acta, 1968, 13, 1329-1341.

77 G. Liu, J. Shi, F. Zhang, Z. Chen, J. Han, C. Ding, S. Chen, Z. Wang, H. Han and C. Li, Angew. Chemie Int. Ed., 2014, 53, 7295-7299.

78 B. C. M. Martindale and E. Reisner, Adv. Energy Mater., 2016, 6 , 1502095.

79 J. Gu, Y. Yan, J. W. Krizan, Q. D. Gibson, Z. M. Detweiler, R. J. Cava and A. B. Bocarsly, J. Am. Chem. Soc., 2014, 136, 830-833.

80 D. W. Wakerley and E. Reisner, Energy Environ. Sci., 2015, 8, $2283-$ 2295

81 U. Mehmood, F. A. Al-Sulaiman, B. S. Yilbas, B. Salhi, S. H. A. Ahmed and M. K. Hossain, Sol. Energy Mater. Sol. Cells, 2016, 157, 604-623.

82 S.-H. Lee, K.-S. Han, J.-H. Shin, S.-Y. Hwang and H. Lee, Prog. Photovoltaics Res. Appl., 2013, 21, 1056-1062.

83 K. R. Phillips, G. T. England, S. Sunny, E. Shirman, T. Shirman, N. Vogel and J. Aizenberg, Chem. Soc. Rev., 2016, 45, 281-322.

84 M. Li, Y. Su, J. Hu, L. Yao, H. Wei, Z. Yang and Y. Zhang, Appl. Surf. Sci., 2016, 361, 11-17.

85 C. Ottone, A. Lamberti, M. Fontana and V. Cauda, J. Electrochem. Soc., 2014, 161, D484-D488. 
M. S. Bobji, S. V. Kumar, A. Asthana and R. N. Govardhan, Langmuir, $2009,25,12120-12126$.

87 B. J. Lee, Z. Zhang, S. Baek, S. Kim, D. Kim and K. Yong, Sci. Rep., 2016, 6, 24653.

88 Y. Li, H. Zhang, T. Xu, Z. Lu, X. Wu, P. Wan, X. Sun and L. Jiang, Adv. Funct. Mater., 2015, 25, 1737-1744.

89 D. Mersch, C.-Y. Lee, J. Z. Zhang, K. Brinkert, J. C. Fontecilla-Camps, A. W. Rutherford and E. Reisner, J. Am. Chem. Soc., 2015, 137, 85418549.

90 M. T. McDowell, M. F. Lichterman, A. I. Carim, R. Liu, S. Hu, B. S. Brunschwig and N. S. Lewis, ACS Appl. Mater. Interfaces, 2015, 7, 15189-15199.

91 D. B. Danko, P. M. Sylenko, A. M. Shlapak, O. Y. Khyzhun, L. G. Shcherbakova, O. G. Ershova and Y. M. Solonin, Sol. Energy Mater. Sol. Cells, 2013, 114, 172-178.

92 P. Ashcheulov, M. Kusko, F. Fendrych, A. Poruba, A. Taylor, A. Jäger, L. Fekete, I. Kraus and I. Kratochvílová, Phys. status solidi, 2014, 211, 2347-2352.

93 J. Luo, L. Steier, M.-K. Son, M. Schreier, M. T. Mayer and M. Grätzel, Nano Lett., 2016, 16, 1848-1857.

94 A. Paracchino, N. Mathews, T. Hisatomi, M. Stefik, S. D. Tilley and M. Grätzel, Energy Environ. Sci., 2012, 5, 8673-8681.

95 S. Hu, M. R. Shaner, J. A. Beardslee, M. Lichterman, B. S. Brunschwig and N. S. Lewis, Science, 2014, 344, 1005-1009.

96 Y. W. Chen, J. D. Prange, S. Dühnen, Y. Park, M. Gunji, C. E. D. 
Chidsey and P. C. Mclntyre, Nat. Mater., 2011, 10, 539-544.

97 Y. Lin, C. Battaglia, M. Boccard, M. Hettick, Z. Yu, C. Ballif, J. W. Ager and A. Javey, Nano Lett., 2013, 13, 5615-5618.

98 J. Azevedo, S. D. Tilley, M. Schreier, M. Stefik, C. Sousa, J. P. Araújo, A. Mendes, M. Grätzel and M. T. Mayer, Nano Energy, 2016, 24, 1016.

99 C. Li, T. Hisatomi, O. Watanabe, M. Nakabayashi, N. Shibata, K. Domen and J.-J. Delaunay, Appl. Phys. Lett., 2016, 109, 33902.

100 Z. Zhang and P. Wang, J. Mater. Chem., 2012, 22, 2456-2464.

101 A. Azarpira, T. Schedel-Niedrig, H.-J. Lewerenz and M. Lublow, Adv. Energy Mater., 2016, 6, 1502314.

102 Z. Li, S. Feng, S. Liu, X. Li, L. Wang and W. Lu, Nanoscale, 2015, 7, 19178-19183.

103 Y.-L. Kuo, C.-C. Wu, Y.-H. Peng and W.-S. Chang, J. Chinese Chem. Soc., 2012, 59, 1323-1328.

104 A. A. Dubale, A. G. Tamirat, H.-M. Chen, T. A. Berhe, C.-J. Pan, W.-N. Su and B.-J. Hwang, J. Mater. Chem. A, 2016, 4, 2205-2216.

105 A. B. Ellis, S. W. Kaiser and M. S. Wrighton, J. Am. Chem. Soc., 1976, 98, 1635-1637.

106 Y. Fan, Y. He, P. Luo, X. Chen and B. Liu, Appl. Surf. Sci., 2016, 368, 435-442.

107 J. Lee and K. Yong, NPG Asia Mater., 2015, 7, e201. 
Table 1. Summary of conventional and emerging protection mechanisms for unstable semiconductor photoelectrodes.

\begin{tabular}{|c|c|c|c|c|c|c|c|}
\hline \multicolumn{3}{|c|}{ Protection mechanism } & \multirow{2}{*}{ Advantages } & \multirow{2}{*}{ Disadvantages } & \multirow{2}{*}{ Coatings } & \multirow[t]{2}{*}{ Electrolyte $(\mathrm{pH})$} & \multirow{2}{*}{$\begin{array}{l}\text { Reported stability } \\
\text { after protection }\end{array}$} \\
\hline Type & Method & Technology & & & & & \\
\hline \multirow{5}{*}{ Conventional } & \multirow{5}{*}{$\begin{array}{l}\text { Thin film } \\
\text { technology }\end{array}$} & PVD & $\begin{array}{l}\text { - Precise overall } \\
\text { composition } \\
\text { control. }\end{array}$ & $\begin{array}{l}\text { - Line-of-sight } \\
\text { deposition. }{ }^{[a]} \\
\text { - May damage the } \\
\text { substrate due to } \\
\text { high-energy } \\
\text { impacts. } \\
\text { - Lack of chemical } \\
\text { control at the } \\
\text { interface. }\end{array}$ & $\begin{array}{l}\mathrm{TiO}_{2}^{53,55,90} \\
\mathrm{NiRuO}_{\times}^{62}\end{array}$ & $\begin{array}{l}\mathrm{TiO}_{2} \\
1 \mathrm{M} \mathrm{HClO}_{4}{ }^{53} \\
1 \mathrm{M} \mathrm{KOH}^{55} \\
1 \mathrm{M} \mathrm{KOH}^{90} \\
\mathrm{NiRuO}_{x}: 0.25 \mathrm{M} \mathrm{NaSO}_{4}(7.2)^{62}\end{array}$ & $\begin{array}{l}\mathrm{TiO}_{2} \\
75 \mathrm{~h}^{53} \\
8 \mathrm{~h}^{55} \\
60 \mathrm{~h}^{90} \\
1.5 \mathrm{~h}^{62[b]}\end{array}$ \\
\hline & & CVD & $\begin{array}{l}\text { - Precise } \\
\text { composition } \\
\text { control and } \\
\text { thickness } \\
\text { control. } \\
\text { - Conformal } \\
\text { coating. }\end{array}$ & $\begin{array}{l}\text { - Limited to } \\
\text { materials with } \\
\text { suitable precursor } \\
\text { volatility, stability } \\
\text { and deposition } \\
\text { chemistry. }\end{array}$ & $\begin{array}{l}\mathrm{TiO}_{2}{ }_{2}^{45} \\
\mathrm{TiO}_{2}{ }^{91} \\
\mathrm{C} \text { (diamond) }\end{array}$ & $\begin{array}{l}0.5 \mathrm{M} \mathrm{H}_{2} \mathrm{SO}_{4}^{45} \\
\text { N/A } \\
\text { N/A }\end{array}$ & $\begin{array}{l}\text { N/A } \\
\text { N/A } \\
N / A\end{array}$ \\
\hline & & CVD (ALD) & $\begin{array}{l}\text { - Conformal and } \\
\text { uniform } \\
\text { deposition on } \\
\text { porous } \\
\text { materials. } \\
\text { - High degree of } \\
\text { thickness } \\
\text { control. } \\
\end{array}$ & $\begin{array}{lr}\text { - Often lengthy } \\
\text { procedures and } \\
\text { with } \quad \text { high } \\
\text { operational costs. }\end{array}$ & $\begin{array}{l}\mathrm{TiO}_{2}{ }^{49,51,53,90,93-97} \\
\mathrm{SnO}_{2}{ }^{98} \\
\mathrm{Ga}_{2} \mathrm{O}_{3}{ }^{99}\end{array}$ & $\begin{array}{l}\mathrm{TiO}_{2} \\
1 \mathrm{M} \mathrm{H}_{2} \mathrm{SO}_{4}{ }^{96} \\
1 \mathrm{M} \mathrm{NaOH}^{96} \\
0.5 \mathrm{M} \mathrm{C}_{8} \mathrm{H}_{5} \mathrm{KO}_{4}(4)^{97} \\
1{\mathrm{M} \mathrm{Phosphate}(7)^{96}} \mathrm{M} \mathrm{KOH}^{90} \\
1 \mathrm{M} \mathrm{HClO}_{4}{ }^{53} \\
\mathrm{SnO}_{2}: 0.5 \mathrm{M} \mathrm{NaSO}_{4}(5)^{98} \\
\mathrm{Ga}_{2} \mathrm{O}_{3}: 0.5 \mathrm{M} \mathrm{NaSO}_{4}(4)^{99}\end{array}$ & $\begin{array}{l}\mathrm{TiO}_{2} \\
8 \mathrm{~h}^{96} \\
8 \mathrm{~h}^{96} \\
12 \mathrm{~h}^{97} \\
18 \mathrm{~h}^{96} \\
60 \mathrm{~h}^{90} \\
72 \mathrm{~h}^{53} \\
\mathrm{SnO}_{2}: 57 \mathrm{~h}^{98} \\
\mathrm{Ga}_{2} \mathrm{O}_{3}: 20 \mathrm{~min}^{99} \\
\end{array}$ \\
\hline & & Electrodeposition & $\begin{array}{l}\text { - Coating of } \\
\text { porous } \\
\text { materials. } \\
\text { - Thickness } \\
\text { control. } \\
\text { - Low } \\
\text { implementation } \\
\text { cost. }\end{array}$ & $\begin{array}{l}\text { - Limited by } \\
\text { deposition } \\
\text { conditions. } \\
\text { - Requires } \\
\text { conductive } \\
\text { substrate/path. } \\
\text { - Often leads to } \\
\text { porous coatings. }\end{array}$ & $\begin{array}{l}\mathrm{CuO}^{100} \\
\mathrm{MoS}_{2+\mathrm{x}}{ }^{1} \\
\mathrm{C}\left(\mathrm{sp}^{2}, \mathrm{sp}^{3}\right)^{101[\mathrm{c}]}\end{array}$ & $\begin{array}{l}0.05 \mathrm{M} \mathrm{NaSO}_{4}(7)^{100} \\
0.5 \mathrm{M} \mathrm{NaSO}_{4}(4)^{51} \\
0.5 \mathrm{M} \mathrm{H}_{2} \mathrm{SO}_{4}{ }^{101}\end{array}$ & $\begin{array}{l}20 \min ^{100} \\
10 \mathrm{~h}^{51} \\
24 \mathrm{~h}^{101}\end{array}$ \\
\hline & & $\mathrm{CBD}^{[\mathrm{d}]}$ & $\begin{array}{l}- \text { Low } \\
\text { implementation } \\
\text { cost. }\end{array}$ & $\begin{array}{l}\text { - Often leads to } \\
\text { porous coatings. }\end{array}$ & $\begin{array}{l}\mathrm{FeOOH}^{102} \\
\mathrm{ZnS}^{103} \\
\mathrm{NiO}_{x}{ }^{64}\end{array}$ & $\begin{array}{l}0.5 \mathrm{M} \mathrm{NaSO}_{4}(7) \\
0.25 \mathrm{M} \mathrm{K}_{2} \mathrm{SO}_{3}, 0.35 \mathrm{M} \mathrm{Na}_{2} \mathrm{~S}(13.3)^{103} \\
0.1 \mathrm{M} \mathrm{NaSO}_{4}(6)\end{array}$ & $\begin{array}{l}2 \mathrm{~h}^{102} \\
5 \mathrm{~h}^{103} \\
20 \min ^{64}\end{array}$ \\
\hline
\end{tabular}




\begin{tabular}{|c|c|c|c|c|c|c|c|}
\hline \multirow{5}{*}{ Emerging } & & Pre-synthesized & $\begin{array}{l}\text { - Leaching. } \\
\text { - Non-optimal } \\
\text { protection. }\end{array}$ & $\begin{array}{l}\text { - Simple } \\
\text { preparation. }\end{array}$ & $\begin{array}{l}\mathrm{ZnFe}_{2} \mathrm{O}_{4}{ }^{75} \\
\mathrm{CuS}^{104} \\
\mathrm{Ni}^{7^{44}}\end{array}$ & $\begin{array}{l}0.5 \mathrm{M} \mathrm{Na}_{2} \mathrm{~S}^{15} \\
1 \mathrm{M} \mathrm{NaSO}_{4}(5)^{104} \\
1 \mathrm{M} \mathrm{NaSO}_{4}(5)^{74}\end{array}$ & $\begin{array}{l}1 \mathrm{~h}^{75} \\
1 \mathrm{~h}^{104} \\
30 \min ^{74}\end{array}$ \\
\hline & Nanoparticles & SSP & $\begin{array}{l}\text { - Low } \\
\text { implementation } \\
\text { cost. } \\
\text { - Simple } \\
\text { procedure. } \\
\text { - Multifunctional } \\
\text { coatings. } \\
\text { - Scalable. }\end{array}$ & $\begin{array}{l}\text { - Lack of film } \\
\text { quality control. } \\
\text { - Lack of conformal } \\
\text { coating. }\end{array}$ & $\begin{array}{l}{\left[(\mathrm{Col}) \mathrm{Ti}_{11} \mathrm{O}_{14}\left(\mathrm{O}^{\prime} \mathrm{Pr}\right)_{171}\right]^{68}} \\
{\left[\mathrm{Ti}_{2}(\mathrm{OEt})_{9}\left(\mathrm{NiCl}_{2}\right]_{2}^{6-6-67,69}\right.} \\
{\left[\mathrm{Ti}_{4}(\mathrm{OEt})_{15}(\mathrm{CoCl})\right]^{65}}\end{array}$ & $\begin{array}{l}0.1 \mathrm{M} \mathrm{K}_{2} \mathrm{SO}_{4}(9.2)^{65} \\
1 \mathrm{M} \mathrm{KCl}(9.2)^{67}\end{array}$ & $\begin{array}{l}24 \mathrm{~h}(30 \% \text { of initial })^{65} \\
4 \mathrm{~h}^{67}\end{array}$ \\
\hline & \multicolumn{2}{|l|}{ Fusible alloys } & $\begin{array}{l}\text { - Recyclability. } \\
\text { - Simple } \\
\text { procedure. } \\
\text { - Double light } \\
\text { path.e] }\end{array}$ & $\begin{array}{l}\text { - Limited to back } \\
\text { illumination. }\end{array}$ & Field's Metal $^{37}$ & $0.1 \mathrm{M}$ borate $(8.5)^{37}$ & $1 h^{37}$ \\
\hline & \multicolumn{2}{|c|}{ Self-healing and regenerating materials } & $\begin{array}{l}\text { - Prolonged } \\
\text { lifetimes. }\end{array}$ & $\begin{array}{l}\text { - Specific to } \\
\text { certain materials. }\end{array}$ & $\begin{array}{l}\mathrm{CoO}_{x}^{20} \\
\mathrm{CuRhO}_{2}{ }^{79} \\
\mathrm{Fe}-\mathrm{FeO}_{\mathrm{x}}{ }^{78} \\
\mathrm{CdS}, \mathrm{CdSe}^{105}\end{array}$ & 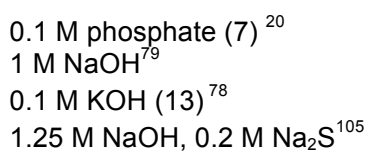 & $\begin{array}{l}50 h^{20} \\
8 h^{79} \\
72 h^{78} \\
10 h^{105}\end{array}$ \\
\hline & \multicolumn{2}{|c|}{ Superhydrophobic materials } & $\begin{array}{l}\text { - Reaction- } \\
\text { protection } \\
\text { feedback. }\end{array}$ & $\begin{array}{l}\text { - Catalyst contact } \\
\text { with electrolyte } \\
\text { diminished. }\end{array}$ & $\begin{array}{l}\mathrm{Fe}^{106} \\
\mathrm{ZnO} / \mathrm{Si}^{107} \\
\mathrm{TiO}_{2} / \mathrm{ZnO}^{85} \\
\mathrm{SiC} / \mathrm{Si}^{87}\end{array}$ & $\begin{array}{l}\text { Water }{ }^{106[\mathrm{f}]} \\
0.4 \mathrm{M} \mathrm{NaSO}_{4}{ }^{107} \\
\mathrm{~N} / \mathrm{A}^{85} \\
0.4 \mathrm{M} \mathrm{NaSO}_{4}{ }^{87}\end{array}$ & $\begin{array}{l}168 h^{106[f]} \\
700 h^{107} \\
N / A^{85} \\
2000 h^{87}\end{array}$ \\
\hline
\end{tabular}

${ }^{a} \mathrm{~A}$ directional deposition effect is observed in line-of-sight deposition techniques, which requires the rotation of $3 \mathrm{D}$ samples in the chamber to achieve a homogeneous deposition. ${ }^{b}$ Accelerated durability test by applying a switching potential test. ${ }^{\mathrm{C}}$ Electropolymerisation. ${ }^{\mathrm{d}} \mathrm{CBD}=\mathrm{Chemical}$ Bath Deposition. ${ }^{\mathrm{e}}$ Since the fusible alloy layer is not transparent, the photoelectrodes are illuminated from the back, which entails that the light traveling through the materials is reflected by the metallic layer, thus effectively providing a double light pass for the devices. In this work, the stability of the superhydrophobicity of the material is assessed by measuring the contact angle after 7 days submerged in water. 
Photoelectrochemical cells

(a)

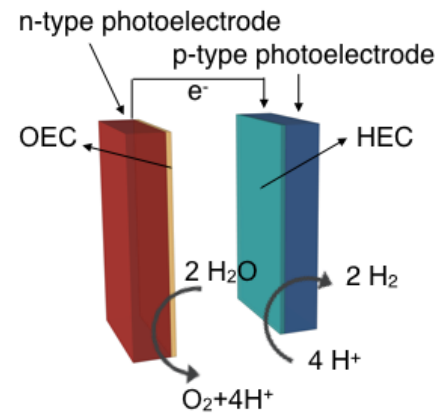

(c)

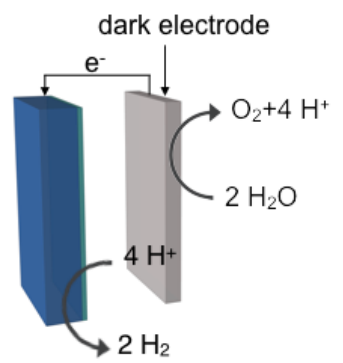

(b)

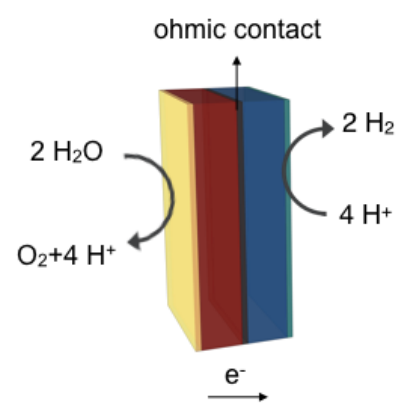

(d)

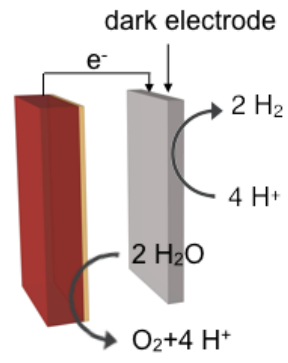

PV-biased photoelectrochemical cells

(e)

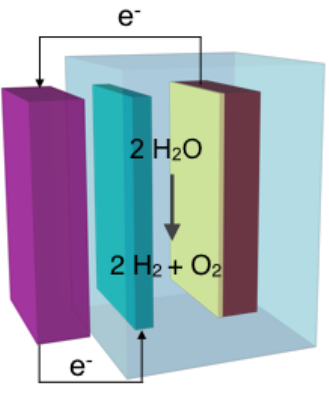

(f)

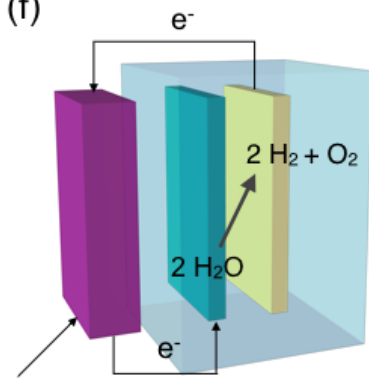

PV element

Fig. 1 Schematic representation of PEC cells where the overall solar-driven water splitting reaction is performed (a) by a pair of complementary photoelectrodes connected in tandem or (b) a monolithic structure with two photoelectrodes connected in series through an ohmic contact. In these configurations, all the electrodes are submerged in an aqueous solution. The photocathode (c) and photoanode (d) can also be used separately to study the corresponding half reactions. An alternative way of generating solar fuels is by combining the use of photovoltaic electrodes with photoelectrodes in a PV-biased PEC cells. (e) It is possible to connect a single PV element with a 
photoelectrode to obtain the necessary voltage to split water, or (f) when a single (or a series of) PV elements is capable of generating enough voltage to split water, the electrode is then wired to suitable catalysts which are submerges in an aqueous solution. 


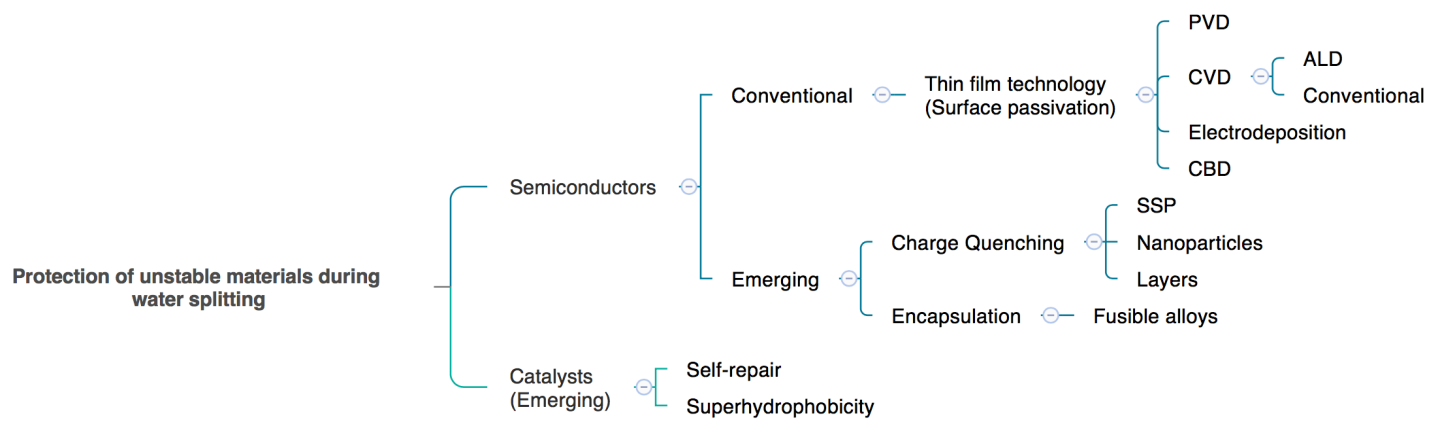

Fig. 2 Conventional and emerging protection approaches used to protect photocorrodible materials during solar fuel applications. 


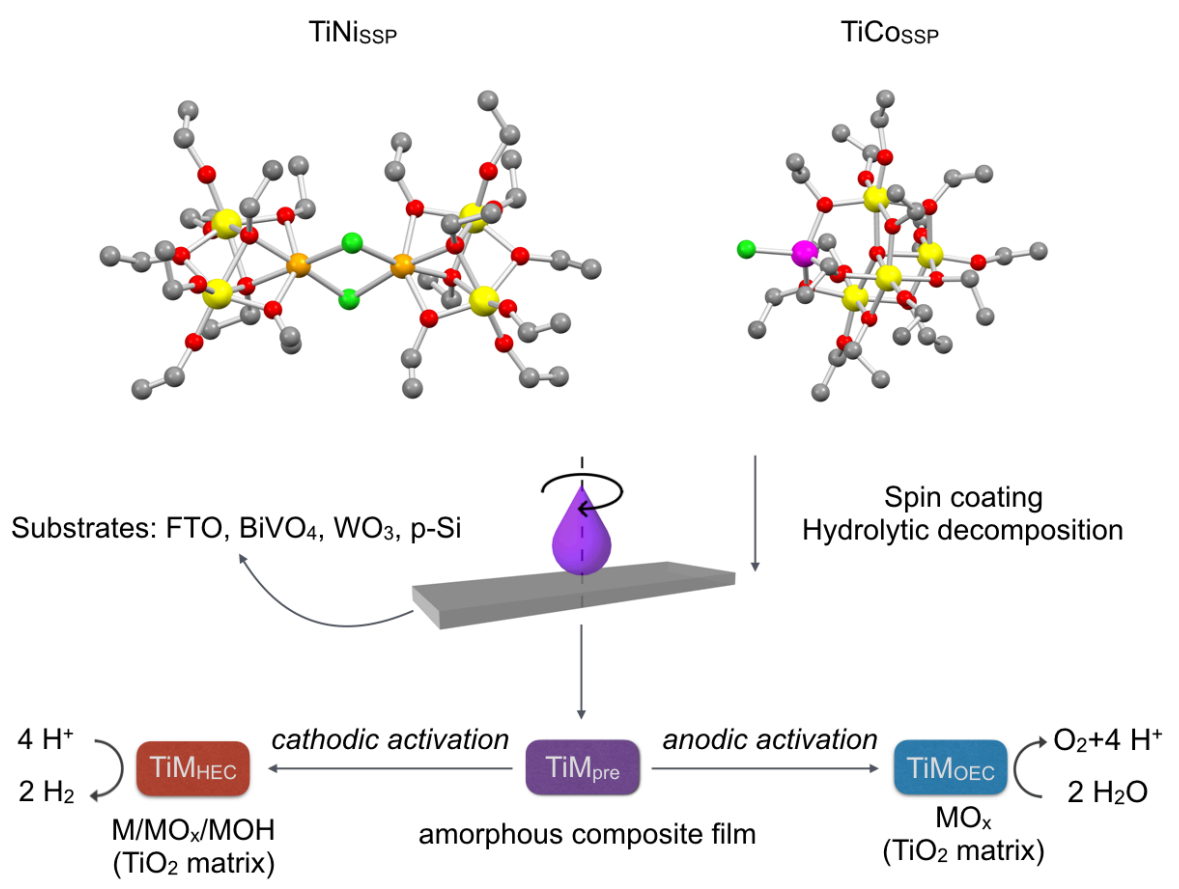

Fig. 3 Molecular structure of $\left[\mathrm{Ti}_{2}(\mathrm{OEt})_{9}(\mathrm{NiCl})\right]_{2} \quad\left(\mathrm{TiNi}_{\mathrm{SSP}}\right)$ and $\left[\mathrm{Ti}_{4} \mathrm{O}(\mathrm{OEt}){ }_{15}(\mathrm{CoCl})\right]\left(\mathrm{TiCossp}_{\text {s }}\right)$ based on crystallographic coordinates $(\mathrm{H}$ atoms and disordered etoxy groups omitted for clarity): $\mathrm{Ti}$ (yellow), Ni (orange), Co (magenta), $\mathrm{Cl}$ (green), $\mathrm{O}$ (red), and C (gray). The precursors were spin coated on different substrates and underwent hydrolytic decomposition that lead to an amorphous composite film containing $\mathrm{Ti}$, Ni/Co atoms, which were transformed to the active HEC or OEC following activation under cathodic or anodic conditions, respectively. Adapted from reference 65 . 
(a)

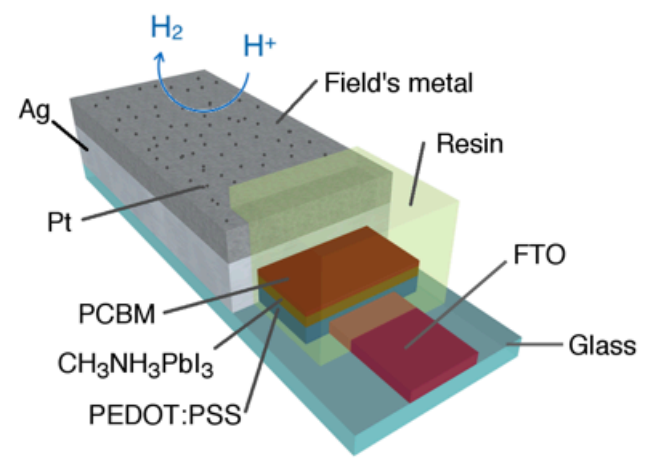

(b)

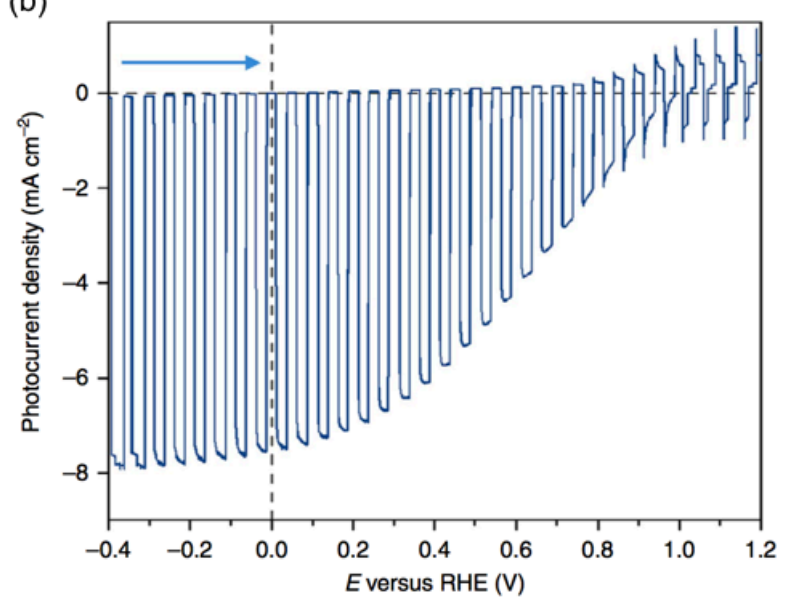

(c)

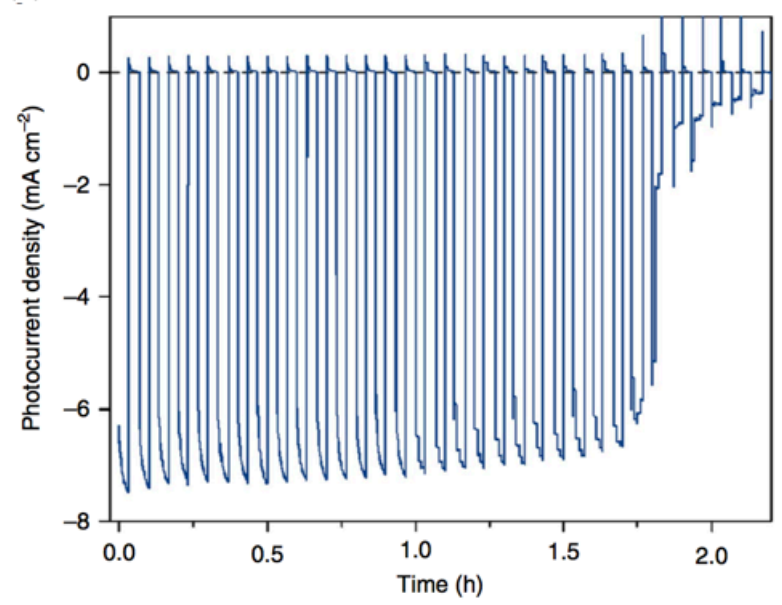

Fig. 4 (a) Schematic representation of the solar $\mathrm{H}_{2}$ producing perovskite (PVK) photocathode. The configuration is based on an inverted p-i-n solar cell coated with a Field's Metal layer and a Pt HEC on top of the Ag layer. (b) Typical linear sweep voltammetry of the PVK-based photocathode. (c) Chronoamperogram recorded with the PVK photocathode at an applied potential of $0 \mathrm{~V}$ versus RHE. An aqueous buffer solution $(0.1 \mathrm{M}$ borate, $\mathrm{pH}$ 


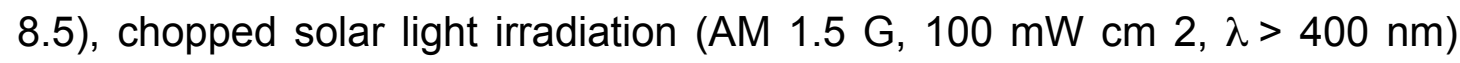
and an inert $\left(\mathrm{N}_{2}\right)$ atmosphere at room temperature were used in both experiments. Adapted from reference 37 . 
(a)

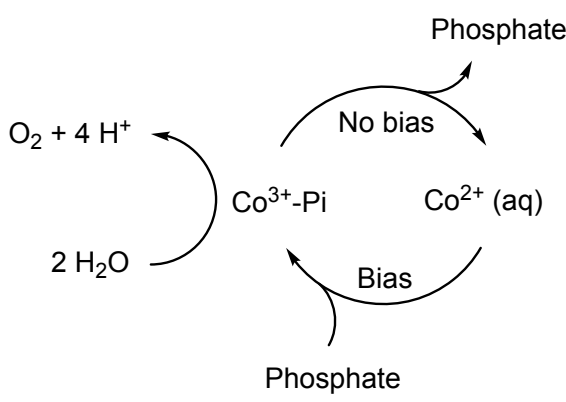

(b)

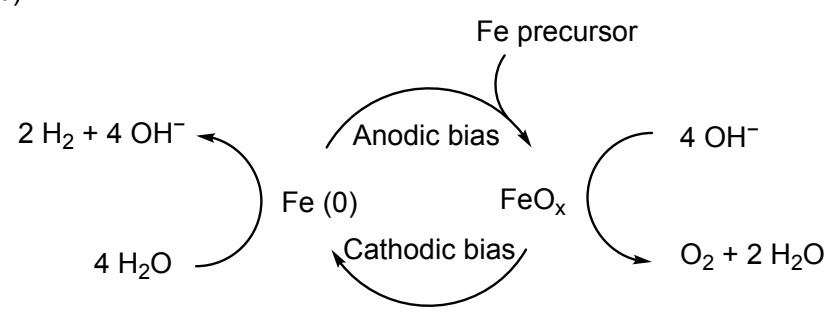

Fig. 5 (a) Schematic representation of the self-repair mechanism of the Co-Pi $\mathrm{O}_{2}$ evolution catalyst in the presence of phosphate under un applied voltage. ${ }^{20}$ (b) Proposed mechanism of the electrochemical reversibility and regeneration of bi-functional iron-only electrodes for water splitting in alkaline solution. An anodic potential generates the active $\mathrm{FeO}_{x}$ species for OER catalysis and a cathodic potential produces $\mathrm{Fe}(0)$ embedded in an iron oxide matrix as HER catalyst. $^{78}$ 
Table of Content artwork

Solar fuel production

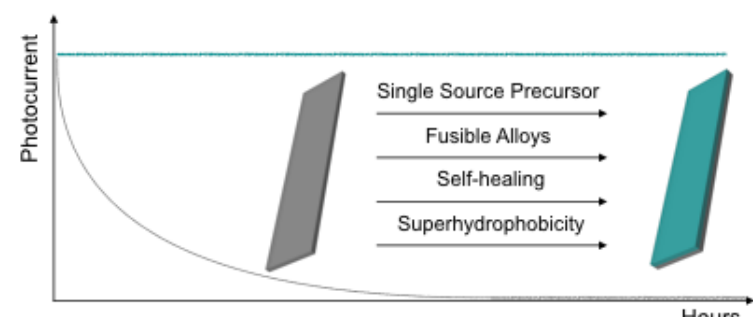

Hours 


\section{Broader Context Statement}

The transformation of solar energy into chemical energy through the generation of solar fuels, or artificial photosynthesis, is one of the most promising routes for tackling the world's fuel demand in a post-fossil era. Photoelectrochemical devices composed of narrow bandgap semiconductors, photovoltaic elements and suitable electrocatalysts are currently considered as one of the main approaches to carry out artificial photosynthesis. However, these materials are often unstable under operating conditions and require protection to prolong their lifetimes. The state-of-the-art protection layer consists of a thin film of $\mathrm{TiO}_{2}$ (combined with other wide bandgap semiconductor materials) deposited by atomic layer deposition. These protection layers, while being able to successfully protect the underlying semiconductors, are operationally costly and difficult to scale up. We herein review alternative emerging techniques to protect both narrow bandgap semiconductors and the accompanying catalysts for solar fuel production. Conventional methods have greatly helped to understand the underlying degradation mechanisms and have paved the way to open new routes, possibly taking inspiration from natural processes such as self-repair, superhydrophobicity and multifunctionality. New research using single source precursor chemistry, fusible alloys and nanotechnology shows that we are ready to step into a new generation of protection methods that are simple, cost-effective and scalable, and are capable of making solar fuels a technologically relevant renewable energy source. 


\section{Biographies and Pictures of the Authors}

Micaela Crespo Quesada received her Msc with Honors in Chemical Engineering from the University of Barcelona in 2007. She then joined the Ecole Polytechnique Fédérale de Lausanne where she completed her PhD in 2011 under the supervision of Prof. Lioubov Kiwi-Minsker on heterogeneous catalysis. After research activities on the structure sensitivity of catalytic hydrogenations, she was awarded a Marie Curie Inter-European Fellowship to Join Dr Erwin Reisner's laboratory at the University of Cambridge in 2014. Her research during the fellowship revolved around finding innovative materials and techniques to exploit highly efficient perovskite materials in the solar fuels field.

Erwin Reisner obtained his PhD at the University of Vienna (with Prof Bernhard K Keppler), followed by postdoctoral research at the Massachusetts Institute of Technology (with Prof Stephen J Lippard) and the University of Oxford (with Prof Fraser A Armstrong FRS). He is currently a University Reader in Energy and Sustainability in the Department of Chemistry at the University of Cambridge, head of the Christian Doppler Laboratory for Sustainable SynGas Chemistry and director of the UK Solar Fuels Network. His laboratory develops solar-driven chemistry by combining chemical biology, synthetic chemistry, materials chemistry and engineering.
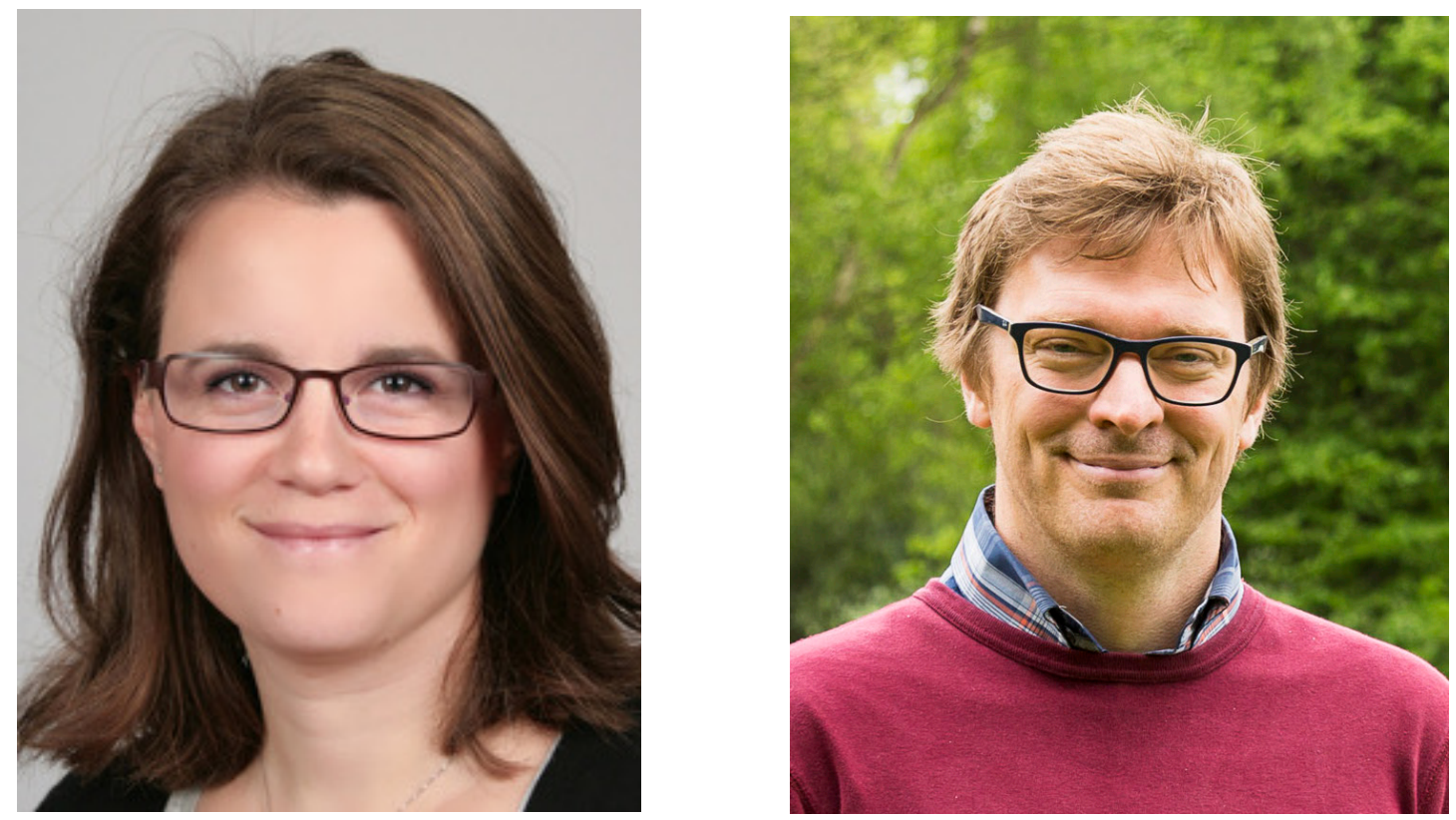